\title{
Lessons from Fukushima: Latest Findings of Thyroid Cancer After the Fukushima Nuclear Power Plant Accident
}

\author{
Shunichi Yamashita, ${ }^{1,2,3}$ Shinichi Suzuki, ${ }^{4}$ Satoru Suzuki, ${ }^{1}$ Hiroki Shimura, ${ }^{5}$ and Vladimir Saenko ${ }^{3}$
}

The increase in risk for late-onset thyroid cancer due to radiation exposure is a potential health effect after a nuclear power plant accident mainly due to the release of radioiodine in fallout. The risk is particularly elevated in those exposed during infancy and adolescence. To estimate the possibility and extent of thyroid cancer occurrence after exposure, it is of utmost importance to collect and analyze epidemiological information providing the basis for evaluation of radiation risk, and to consider radiobiology and molecular genetics. In this regard, the doseresponse of cancer risk, temporal changes in the rates of thyroid cancer, its histopathological types and subtypes, and frequency of underlying genetic abnormalities are important. At present, however, it is difficult or impossible to distinguish radiation-induced thyroid cancer from spontaneous/sporadic thyroid cancer because molecular radiation signatures, biomarkers of radiation exposure, or genetic factors specific to radiation-induced cancer have not yet been identified. The large-scale ultrasound screening in Fukushima Prefecture of Japan demonstrated a high detection rate of thyroid cancer in young individuals, revealing 116 and 71 cases in the first and second rounds, respectively, among the same cohort of approximately 300,000 subjects. These findings raised concerns among residents and the public that it might be due to putative exposure to radiation from the accident at Fukushima Daiichi Nuclear Power Plant. This review summarizes evaluations by international organizations and reviews scientific publications by the authors and others on childhood thyroid cancer, especially those relevant to radiation, including basic studies on molecular mechanisms of thyroid carcinogenesis. Clinical details are also provided on surgical cases in Fukushima Prefecture, and the effect of thyroid ultrasound screening is discussed. Correct understanding of issues relating to radiation and the thyroid are essential for interpretation of thyroid cancer in Fukushima.

Keywords: Fukushima, thyroid cancer, ultrasound thyroid screening, thyroid surgery, radiation exposure, Chernobyl

\section{Introduction}

A FTER The Great EAst Japan Earthquake and the following giant tsunami on March 11, 2011, a serious accident occurred at the TEPCO Fukushima Daiichi Nuclear Power Plant. Radioactive materials resultantly spread in Fukushima Prefecture (Fukushima city, the capital) and throughout East Japan, leading to the evacuation of some 165,000 residents (about $8 \%$ of the prefectural population) from designated evacuation areas (about $8 \%$ of the territory of Fukushima Prefecture) by March 2012. The multiple disasters and nuclear power plant accident gave rise to considerable alarm among the residents about the influence of radiation on their health. In response to these concerns, the Fukushima Health Management Survey was launched in July 2011 as a means of additional healthcare for residents (1-3).

Radiation epidemiology data, based on the results of the long-term study of radiation effects on atomic bomb survivors in Hiroshima and Nagasaki, unambiguously demonstrate that thyroid cancer risk is increased by external radiation exposure in a dose- and age-dependent manner (4). A sharp increase in the incidence of childhood thyroid cancer in Belarus was

\footnotetext{
${ }^{1}$ Radiation Medical Science Center for the Fukushima Health Management Survey, Fukushima Medical University, Fukushima, Japan Departments of ${ }^{2}$ Radiation Medical Sciences and ${ }^{3}$ Radiation Molecular Epidemiology, Atomic Bomb Disease Institute, Nagasaki University, Nagasaki, Japan. Japan.

Departments of ${ }^{4}$ Thyroid and Endocrinology and ${ }^{5}$ Laboratory Medicine, Fukushima Medical University School of Medicine, Fukushima,
}

(c) Shunichi Yamashita et al. 2018; Published by Mary Ann Liebert, Inc. This is an Open Access article distributed under the terms of the Creative Commons Attribution License, which permits unrestricted use, distribution, and reproduction in any medium, provided the original work is properly cited. 
initially reported four to five years after the Chernobyl accident (5). Given the dose-dependent thyroid cancer risk and the results of in vitro irradiation experiments showing that high-dose exposure induces genetic alterations such as gene rearrangements seen in thyroid cancer tissues (6-8), radiation exposure is undoubtedly a risk factor for thyroid cancer.

It is now becoming evident that exposure doses in $\mathrm{Fu}-$ kushima residents are much lower than those from the Chernobyl accident, and no strong evidence in support of the causal relation of thyroid cancer with radiation exposure in Fukushima is available so far $(9,10)$. Thus, good epidemiological studies are still in demand. While reports by international agencies on the Fukushima accident state that proving the causal relation under such low exposure ranges is extremely difficult $(11,12)$, the analyses of genetic abnormalities and pathological characteristics are now in progress to offer some clues on the possible etiology of papillary thyroid carcinoma (PTC) in Fukushima patients.

Before discussing issues related to thyroid cancer in Fukushima and lessons learned, this review briefly provides an overview on the most relevant findings in the areas of radiation epidemiology, and addresses some aspects of the Chernobyl accident and molecular characteristics of PTC in order to demonstrate how they apply to Fukushima.

\section{Epidemiological Studies of Radiation Exposure and Thyroid Cancer}

To clarify the relationship between a disease and possible causes using an epidemiological study method, the validity of the causal relationship must first be verified. Essentially, five criteria must be met: the consistency of association (universality of association among humans, places, and time), the strength of association (quantity-reaction association), the specificity of association (the validity of cause and outcome), the temporality of association (the temporal order of cause and outcome), and the coherence of association (nonconflicting with substantive knowledge) (13).

As for the development of thyroid cancer after radiation exposure, the cause has been presumed reasonable, and the risk has been quantified, considering these criteria. The results of epidemiological studies in various groups exposed to radiation can be summarized as follows. Both external $(14,15)$ and internal radiation exposure, as occurred after the Chernobyl accident (16), increase thyroid cancer risk. Although the results in either case depend on the accuracy of dose estimates and reliability of the long-term follow-up (cancer registration and death certificates), it is possible to conclude that cancer risk increases dose dependently, even if uncertainties are considered. Based on the results of the analysis in atomic bomb survivors and other groups exposed to radiation, the risk of thyroid cancer largely increases at exposure doses $>100 \mathrm{mSv}$, which is an international consensus $(17,18)$. Recent reports, however, suggest the existence of a dose-dependent trend even below this exposure level $(14,15)$. Since many cases of thyroid cancer are being diagnosed in patients without a history of radiation, the five criteria mentioned above must be considered in order to establish the causality between thyroid cancer and radiation.

Effective doses to the thyroid in the general population after the Fukushima accident have been estimated to be less than several $\mathrm{mSv}$ for the majority of people, including infants and children $(11,12)$. No radiation level corresponding to thyroid dose $>50 \mathrm{mSv}$ was detected among 1080 children directly examined with a scintillation survey meter at the end of March 2011 (the highest 95th percentile, $20.9 \mathrm{mSv}$ in Iwaki city) (19). Further discussions regarding the risk based on these estimates are necessary. What is important in understanding and interpreting the results of thyroid ultrasound examinations in Fukushima is the advanced ability of scientific thinking and explanation, taking into account the fact that the natural history of asymptomatic abnormalities in infants, children, adolescents, and young adults is now being clarified through the introduction of a large-scale screening program. Claims based only on the numbers of detections are irrational; it is necessary to contemplate demographic characteristics of the population and its size, the type of exposure, the dose and dose rate, thyroid examination method, and its detection sensitivity, as well as other confounding factors. Especially in case of low-dose exposures, relevance to confounding factors, such as hereditary predisposition, iodine deficiency, hyperthyrotropinemia, obesity, smoking, various hormone levels, and possible exposure to carcinogenic chemicals, needs to be addressed $(20,21)$. So far, the international agencies and scientific experts support the notion that in view of low doses to the public, the increase of radiation-related risk for thyroid cancer is highly unlikely $(11,12,22)$.

\section{Thyroid Cancer After Chernobyl Nuclear Power Plant Accident}

During the first five years after Chernobyl, the only source of data on thyroid cancer was from cancer registries, and no systematic ultrasound screening program had been implemented at that time. In Belarus, the cancer registry was well developed even before the accident, and all childhood thyroid surgeries were performed in the Thyroid Tumor Centre in Minsk city, from which the first report on the increase in the number of children with thyroid cancer was published in 1992 (5). Based on the increase in the number of cases with years after the report, it has been suggested as circumstantial evidence of the link with the Chernobyl accident (Fig. 1). Similar reports were submitted later from Ukraine and Russia (23).

Estimation of the internal thyroid doses progressed after that, and the increase of thyroid cancer risk due to internal exposure to radioactive iodine was clarified; the risk was seen in individuals $<18$ years of age at the time of accident. The results of case-control studies through international cooperation also demonstrated the increase in the risk for PTC among those who were exposed to relatively high doses to the thyroid (16). Currently, cohort studies are continuing in Belarus and Ukraine in cooperation with the United States, and both studies concordantly reported the existence of similar dose-dependent thyroid cancer risks from radiation $(24,25)$. Thus, the increase of thyroid cancer risk has been epidemiologically confirmed after the Chernobyl accident.

One point that should be noted is the degree of contribution from enhanced medical assessment to the increase in the number of surgeries for thyroid cancer (26). A recently conducted study that set out to compare the incidence of thyroid cancer in the population $<18$ years of age at exposure to Chernobyl fallout, which is under medical surveillance, with corresponding nationwide data found an increase of 6.7 averaged for the period from 1991 to 2013 (27). 


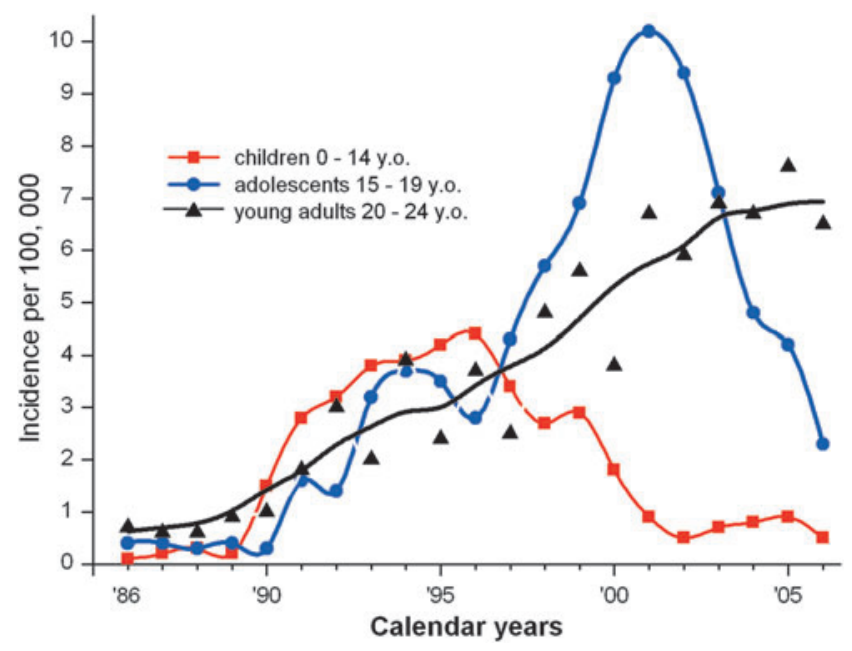

FIG. 1. Incidence of thyroid cancer in patients of different age groups at diagnosis in Belarus after the Chernobyl accident. Data are derived from the same set as in Demidchik et al. (23).

\section{Genetic Alterations in Thyroid Cancer Resulting from Radiation Exposure}

PTC is generally the most common histological type of thyroid cancer, and the increase in thyroid cancer post Chernobyl has been largely limited to PTC. Constitutive activation of the MAP kinase signaling pathway has been confirmed for the majority of tumors. The most characteristic alterations include gene rearrangements, among which the $R E T / P T C$ family is the most abundant, and point mutations of the $B R A F\left(B R A F^{V 600 E}\right)$ and $R A S$ family genes (28). These oncogenic alterations typically occur in a mutually exclusive manner in cancerous tissue. There is a high frequency of $B R A F^{V 600 E}$ in PTC from adult patients without a history of radiation exposure $(28,29)$.

With regard to gene rearrangements, many in vitro and in vivo experimental results on the effects of radiation have been reported, and the molecular mechanism of repairing DNA damage is now being elucidated. For example, it has been proposed that the structural basis of RET/PTC1 formation might be due to a propensity of recombination of the $R E T$ and CCDC6 loci after DNA double-strand breakage in the loop structure in the $16.1 \mathrm{Mb}$ region of chromosome $10 \mathrm{q} 11.21$ (30).

As for the relevance to radiation exposure, although there are results on the induction of chromosomal rearrangements in in vitro high-dose irradiation experiments $(6,8)$ and in PTC tissues from atomic bomb survivors exposed to high doses $(7,31)$, the reproducibility is low or absent at low-dose or low dose-rate irradiation, and do not provide insights into signature genes, which would be characteristic of radiationinduced thyroid cancer. In some cases of internal thyroid exposure during infancy in Chernobyl, a higher frequency of RET/PTC3 rearrangements has been found in early-onset childhood thyroid cancers with a latency from 5 to 10 years (32). Gene rearrangements are indeed frequent in early-onset childhood thyroid cancers in Chernobyl cases, and it is important to perform an analysis comparing those with sporadic cases matched by age and considering possible differences in ethnicity and geographic region. Although other gene rearrangements said to be more frequent in radiation-related PTC have also been reported (33), they need to be reexamined in sporadic childhood thyroid cancers, in which the same rearrangements may occur at lower frequencies. In addition, the types of gene rearrangements are diverse, and they are also found in sporadic adult PTC, although at a reduced frequency. The results of genetic analyses show that fusion genes, which are frequent $(33-85 \%)$ in children and adolescents, have also been observed in adult PTCs at a rate of about $14 \%$ (34).

Thus, further investigations are necessary to reveal the mechanism explaining the age-dependent difference in the rearrangement frequency: at what age and how the frequency of rearrangement decreases in adult thyroid cancers and why $B R A F^{V 60 O E}$, which is rare or less frequent in childhood, drastically increases after adolescence. A study of operated cancer cases in Fukushima has revealed that the profile of genetic alterations is similar to that of adult sporadic PTC (Fig. 2) $(35,36)$. One possible explanation would be that thyroid cancers in young Fukushima patients might be a result of early detection of PTCs, which may (or may not) become clinically significant in adulthood, due to screening.

There are also reports on other molecular characteristics, such as differences in gene expression between normal and cancer tissues $(37,38)$. So far, no reliable molecular signature has been established. An analysis of Chernobyl cases reported that $C L I P 2$, which is located on chromosome 7q11.23, is specifically amplified in a subset of cases compared to unexposed PTCs, and that on immunohistochemistry, a significant difference in the level of protein expression is observed (39). Further studies, including analyses with more advanced technologies such as next-generation sequencing, are necessary to identify molecular signatures associated with radiation exposure.

\section{Susceptibility to Radiation-Induced Thyroid Cancer}

Hereditary factors may contribute to the risk of developing a disease at the individual level. Applicable to the risk for radiation-related thyroid cancer, finding markers of susceptibility or resistance in order to understand why some individuals develop malignancy after exposure to a similar dose of radiation while the vast majority does not would be a substantial advance. Genetic association studies in sporadic thyroid cancer lead to the identification of four chromosomal loci with five single-nucleotide polymorphisms (SNPs) displaying the following most significant association signals: rs966423 (DIRC3), rs2439302 (NRG1), rs965513 (PTCSC2/ FOXE1), rs944289 (PTCSC3), and rs116909374 (MBIP1) (40-42), and an additional study, using an extremely large cohort, recently discovered six novel chromosomal regions whose effects are less pronounced (43). The strongest association signal was detected for rs965513 (PTCSC2/FOXE1) located on chromosome 9q22.33. A genome-wide association study using Chernobyl cases showed a strong association of SNPs in the same FOXE1 region, but no markers specific for radiation-induced thyroid cancer have been found to date (44).

In a study of the Japanese population, rs965513 (PTCSC2/ FOXE1) and rs944289 (PTCSC3) also showed significant association with sporadic PTC, although variant allele frequencies 


\section{Chernobyl regions}

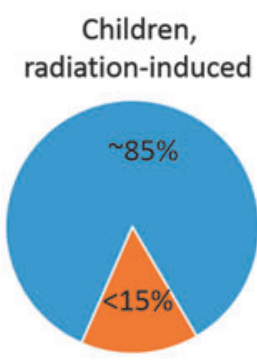

$13-23$ (18)

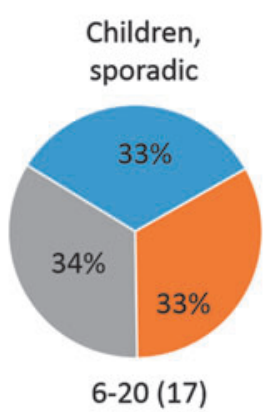

$6-20(17)$

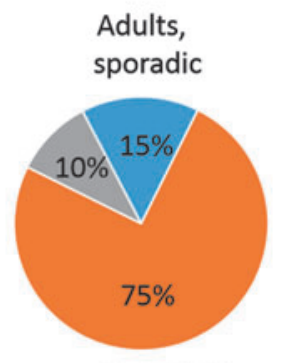

$13-87(51)$
Japan

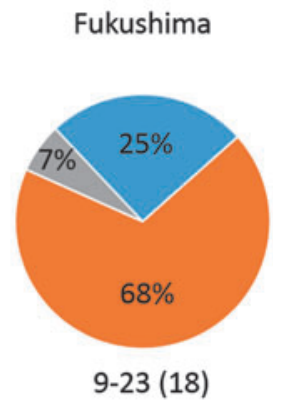

(rounded mean age) of patients.

Data are summarized from different publications.

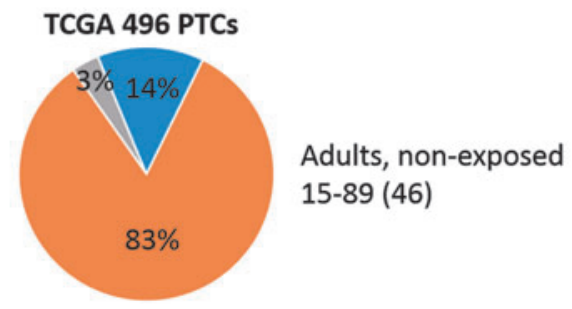

Point mutations

Gene rearrangements

Unknown alterations

are low (45-47). Future SNP analyses of Fukushima cases are also awaited.

Since thyroid carcinogenesis in FOXE1 overexpression mice has not been confirmed, regardless of exposure to radiation (48), a further search of susceptibility markers is needed with advanced technologies including the analysis of gene-environmental interactions.

\section{Outline of the Fukushima Health Management Survey Project}

After the compound disaster in East Japan in March 2011, the Japanese Government and Fukushima Prefecture established a fund for the long-term health management of Fukushima residents and started the Fukushima Health Management Survey (3). The project consists of a basic survey for estimating the external exposure doses for the initial four months and four detailed surveys, one of which is a thyroid ultrasound examination (Fig. 3).

The basic survey was started in July 2011, and thyroid ultrasound examinations took place in October of the same year $(49,50)$. While the initial external exposure was of the greatest concern, it subsequently became clear that the doses were $<1 \mathrm{mSv}$ for the majority of the two million residents in Fukushima, and $1-5 \mathrm{mSv}$ for the forced evacuees, with one case of resident with a maximum of $25 \mathrm{mSv}$ exposure (51). Other important estimates of the internal thyroid equivalent dose in the residents evacuated from the sites in vicinity of the Fukushima Nuclear Power Plant are nearly all $<30 \mathrm{mSv}$, although the uncertainty is large (19).

In the middle of confusion and absent information on external and internal dose estimates, the thyroid ultrasound examinations were started in October 2011 for all residents aged $\leq 18$ years at the time of accident in Fukushima (49). In brief, only thyroid ultrasound is performed during the primary examination at any screening cycle. Using strict ultrasound examination criteria and a defined protocol, and based on the finding $\mathrm{A}, \mathrm{B}$, or $\mathrm{C}$ (Table 1), the resident is then instructed to have one of three types of examination: finding $\mathrm{A}$ - the same examination at the next screening; $\mathrm{B}$-confirmatory examination covered by health insurance; or $\mathrm{C}$-an immediate confirmatory examination. In the latter situation, the resident undergoes an additional elaborate ultrasound examination, a blood test for measuring the thyroid function and autoantibodies, and a urine analysis to measure iodine secretion. Fine-needle aspiration cytology (FNAC) is recommended if sonographic findings of nodules or cysts correspond to FNAC criteria for potential malignancy (52). According to the survey protocol, examinations are conducted every two years for each resident until the 20 years of age and every five years thereafter.

\section{Results of Thyroid Ultrasound Examinations in Fukushima}

A preliminary screening was conducted as the first examination in the period from October 9, 2011, until March 31, 2014, and considered to be the baseline survey. This and consecutive screening rounds were performed successively in municipalities in the descending order of air dose. In the two years between April 1, 2014, and March 31, 2016, the second round, or the first full-scale survey, was completed, and currently the second full-scale survey, which is the third round, is underway (see Fig. 3). The results of thyroid ultrasound examinations have been summarized elsewhere (53), and an update is provided here according to the most recent Prefectural Oversight Committee Meeting for $\mathrm{Fu}-$ kushima Health Management Survey held on June 5, 2017.

In brief, sonographic results are classified into three major categories: A, B, or C (see Table 1). As shown in Table 2, in the preliminary baseline screening, the percentage of subjects receiving the primary examination was $81.7 \%$ of the target population of 367,649 persons, and the number of those needing confirmatory examination was 2294, combining the B and C categories. FNAC was performed in 547/2130 subjects who had undergone a confirmatory examination, and 


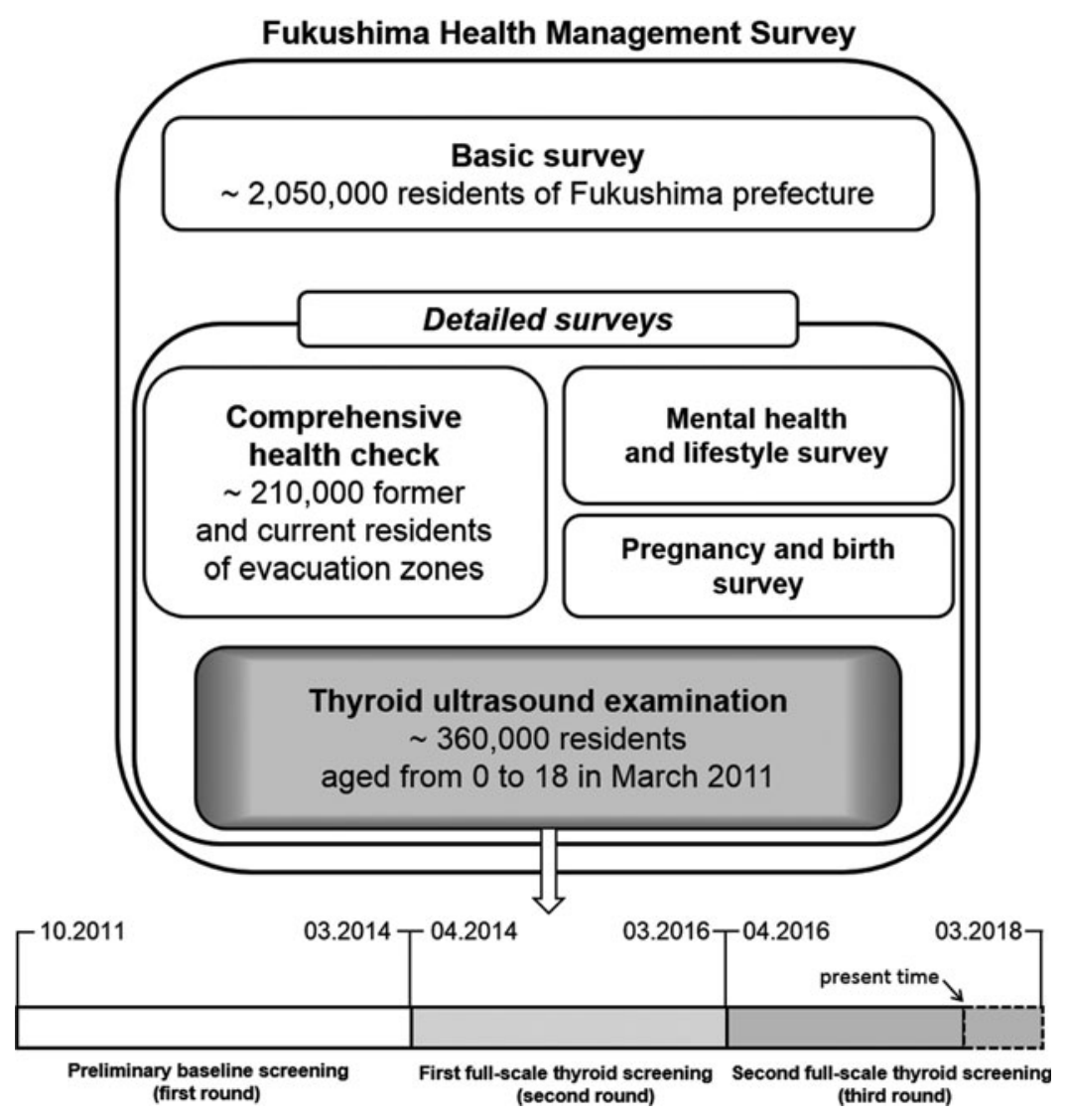

FIG. 3. Outline of the Fukushima Health Management Survey, and calendar terms and official titles of thyroid ultrasound screening cycles. Information is from the Radiation Medical Science Center, Fukushima Medical University website (86).

116 subjects were diagnosed as having suspicious or malignant lesions. Of those 116 subjects, 102 have already received surgery, with 101 being diagnosed with thyroid cancer and one as having a benign tumor (54).

In the first full-scale survey, which was the second-round screening, the participation rate in the primary examination was $71.0 \%$ of 381,256 people. Among them, 2226 subjects required a confirmatory examination because of a category $B$ finding in the primary examination. FNAC revealed 71 subjects with malignant or suspicious for malignancy results after examining 1832 patients $(82.3 \%$, the confirmatory examination rate). Of them 44 underwent surgery, and all were diagnosed with thyroid cancer. The rate of a category B finding in the preliminary (or the first round) and the following full-scale (or the second round) screening cycles was both $0.8 \%$. The rate of a category A2 finding increased from $47.8 \%$ in the preliminary screening to $59.0 \%$ in the full-scale screening (54).

Some subjects identified during either the preliminary or the following full-scale surveys with nodules judged malignant or suspicious of malignancy have been under observation without undergoing surgery. Among 187 subjects diagnosed with nodules categorized as malignant or suspicious for malignancy in the first two examinations, 146 underwent surgery (including one case that was shown to be benign on postoperative pathology examination), and 41 are scheduled for surgery or are under observation without a definite plan for surgery. The latter are those who have tumors with a diameter $<10 \mathrm{~mm}$ and are not suspected of having lymph node metastasis, extrathyroidal tumor extension, or distant metastasis. The observation includes blood tests and ultrasound examinations at time intervals from about six months to one year. If any of them are moving to attend college or to be employed outside Fukushima Prefecture, or if an increase in tumor size is observed, the subject and/or the parents/guardians usually prefer to choose surgery.

The intermediate result of the third-round survey shows a similar diagnostic trend. Although collecting information on cancer takes time, it is expected that data analysis will continue to progress, including data for FNAC and operated cases. As of March 31, 2017, 35.8\% of participants of the

Table 1. Classification of Thyroid Ultrasound Examination Results in the Screening Program in Fukushima Prefecture

\begin{tabular}{lll}
\hline Examination result & \multicolumn{1}{c}{ Definition } & \multicolumn{1}{c}{ Recommended action } \\
\hline A & & \\
A1 & No nodules or cysts & Participation in the next scheduled screening \\
A2 & Nodules $\leq 5.0 \mathrm{~mm}$ or cysts $\leq 20.0 \mathrm{~mm}$ & Watchful waiting until the next scheduled screening \\
B & Nodules $\geq 5.1 \mathrm{~mm}$ or cysts $\geq 20.1 \mathrm{~mm}$ & Confirmatory examination by health insurance \\
C & Suspicious finding other than A2 or B & Immediate need for confirmatory examination \\
\hline
\end{tabular}


Table 2. Results of Ultrasound Thyroid Screening in Fukushima Prefecture

\begin{tabular}{|c|c|c|c|}
\hline & $\begin{array}{l}\text { Preliminary baseline } \\
\text { screening }\end{array}$ & $\begin{array}{l}\text { First full-scale } \\
\text { thyroid screening }\end{array}$ & $\begin{array}{l}\text { Second full-scale } \\
\text { thyroid screening }\end{array}$ \\
\hline Terms, fiscal years ${ }^{\mathrm{d}}$ & 2011-2013 & 2014-2015 & 2016-present \\
\hline Target population & $367,649(100.0 \%)$ & $381,256(100.0 \%)$ & $336,616(100.0 \%)$ \\
\hline \multicolumn{4}{|l|}{ Primary examination } \\
\hline Subjects examined & $300,473(81.7 \%)$ & $270,511(71.0 \%)$ & $120,596(35.8 \%)$ \\
\hline Examination result confirmed ${ }^{\mathrm{e}}$ & $300,473(81.7 \%)$ & $270,497(70.9 \%)$ & $105,966(31.5 \%)$ \\
\hline Finding $\mathrm{A}$ (\% of examination result confirmed) & $298,179(99.2 \%)$ & $268,271(99.2 \%)$ & \\
\hline A1 & $154,605(51.5 \%)$ & $108,697(40.2 \%)$ & $36,928(34.8 \%)$ \\
\hline A2 & $143,574(47.8 \%)$ & $159,574(59.0 \%)$ & $68,347(64.5 \%)$ \\
\hline $\mathrm{B}$ & $2293(0.8 \%)$ & $2226(0.8 \%)$ & $691(0.7 \%)$ \\
\hline $\mathrm{C}$ & $1(\sim 0 \%)$ & $0(0 \%)$ & $0(0 \%)$ \\
\hline \multicolumn{4}{|l|}{ Confirmatory examination } \\
\hline Subjects $(B+C)$ & $2294(100.0 \%)$ & $2226(100.0 \%)$ & $691(100.0 \%)$ \\
\hline Participated & $2130(92.9 \%)$ & $1832(82.3 \%)$ & $332(48.0 \%)$ \\
\hline Examination result confirmed ${ }^{\mathrm{e}}(\%$ of participated) & $2090(98.1 \%)$ & $1748(95.4 \%)$ & $225(67.8 \%)$ \\
\hline Finding A ( $\%$ of examination result confirmed) & $711(34.0 \%)$ & $418(23.9 \%)$ & $24(10.7 \%)$ \\
\hline A1 & $132(6.3 \%)$ & $61(3.5 \%)$ & $1(0.4 \%)$ \\
\hline A2 & $579(27.7 \%)$ & $357(20.4 \%)$ & $23(10.2 \%)$ \\
\hline Other than A & $1379(66.0 \%)$ & $1330(76.1 \%)$ & $201(89.3 \%)$ \\
\hline FNAC performed ( $\%$ of other than $A$ ) & $547(39.7 \%)$ & $200(15.0 \%)$ & $11(5.5 \%)$ \\
\hline \multicolumn{4}{|l|}{ Suspicious or malignant on FNAC } \\
\hline Patients & 116 & 71 & 4 \\
\hline Sex M/F (ratio) & $39 / 77(1: 2.0)$ & $32 / 39(1: 1.2)$ & $2 / 2(1: 1)$ \\
\hline Mean age at diagnosis ( $S D$, range), years & $17.3(2.7,8-22)$ & $16.9(3.2,9-23)$ & $15.5(2.1,13-18)$ \\
\hline Mean age at accident ( $S D$, range), years & $14.9(2.6,6-18)$ & $12.6(3.2,5-18)$ & $10.3(2.1,8-13)$ \\
\hline
\end{tabular}

${ }^{\mathrm{a}}$ Information according to Radiation Medical Science Center, Fukushima Medical University (83).

b Information according to Radiation Medical Science Center, Fukushima Medical University (84).

${ }^{\mathrm{c} I n f o r m a t i o n}$ as of March 31, 2017, according to Radiation Medical Science Center, Fukushima Medical University (85).

${ }^{\mathrm{d}}$ Fiscal and academic year in Japan begins on April 1 of a given calendar year and ends on March 31 of the next calendar year.

${ }^{\mathrm{e}}$ Recorded ultrasound image judged interpretable after reviewing.

FNAC, fine-needle aspiration cytology; $S D$, standard deviation.

target population of 336,616 persons were examined. Among them, 691 needed confirmatory examinations. FNAC was performed in 11 patients, and four cases were deemed to have suspicious or malignant lesions (54).

In addition, as by-products of the large-scale thyroid ultrasound examinations, the growth curves of thyroid volume by age and sex, and ultrasonographic appearance and the frequency of ectopic intrathyroidal thymus and thyroid hemiagenesis have been reported (55-57).

\section{Surgical Findings in Childhood, Adolescent, and Young Adult Thyroid Cancer in Fukushima}

Out of 146 surgical cases, 126 patients underwent surgery at Fukushima Medical University Hospital, and 125 were postoperatively diagnosed with thyroid cancer $(52,58)$. The following is a detailed report on these 125 cases. The male-tofemale ratio was $1: 1.8$. Age at the time of diagnosis was 9-23 years old $\left(M_{\text {age }}=17.8 \pm 3.1\right.$ years $)$, and age at the time of the earthquake was 5-18 years old $\left(M_{\text {age }}=14.8 \pm 2.7\right.$ years $)$. The maximum tumor diameters were 5-53 $\mathrm{mm}(M=14 \pm 8.5 \mathrm{~mm})$. The location of the tumor was unilateral in $121(96.8 \%)$ cases and bilateral in four $(3.2 \%)$ cases. Among the unilateral cases, 68 were in the right lobe and 53 in the left lobe.

There were 44 cases of thyroid microcarcinomas without signs of invasion or metastasis before surgery. Among these cases, 11 patients chose surgery for the reasons described above, despite non-surgical follow-up being recommended.
Among the remaining 33 cases, 20 displayed extension beyond the thyroid capsule (EX1), three had lymph node metastasis, 10 were suspected of having invasion of the recurrent laryngeal nerve, seven had a suspected of invasion of the trachea, one case had coexisting Graves' disease, and one had a concomitant lung tumor. Most microcarcinomas were identified as non-encapsulated neoplasias both before surgery and on pathology after surgery.

The mean tumor diameter of operated thyroid cancers in Fukushima (14 mm) and the rate of distant metastasis (2\%) are in contrast with a past report on childhood thyroid cancer in Japan (59). According to that study, the average tumor diameter and the rate of lung metastases were $40 \mathrm{~mm}$ and $19 \%$, respectively (59), which indicates that before the screening in Fukushima, childhood thyroid cancers were usually detected at a more advanced stage.

\section{TNM classification}

In the preoperative clinical TNM (cTNM) classification, cT1 was $80.8 \%$, cT2 and cT3 (EX1) were $9.6 \%$ each, and no cases of cT4 (EX2) were identified. All cT3 tumors were cEX1 and had a tumor size $>4 \mathrm{~cm}$ in two cases. cN1 was $22.4 \%$. Three cases were classified as M1. all patients had lung metastasis diagnosed on preoperative CT.

In the postoperative pathological TNM (pTNM) classification, pT1 was $59.2 \%$, pT2 $1.6 \%$, pT3 39.2\%, and there were no cases of pT4. Comparing with the preoperative data, 
T1b and T2 decreased, while T3 (EX1) markedly increased. pN1 was $77.6 \%$ in contrast to the preoperative data, showing a marked increase. N1b for the lateral lymph nodes roughly remained the same. Since lateral lymph node dissection (D2, D3) was performed only in the cases diagnosed with positive findings on computed tomography (CT) and/or ultrasound imaging and/or FNAC, the preoperative and postoperative rates did not differ markedly. By contrast, N1a (D1) increased from $4 \%$ to $60.8 \%$, which seems to reflect the fact that lymph node metastasis in the tracheal area is not easily detected on preoperative $\mathrm{CT}$ or ultrasound examination. Prophylactic dissection of lymph nodes on the affected side, including tracheal lymph nodes, was performed in all cases.

\section{Surgical methods}

Total thyroidectomy was performed in $11(8.8 \%)$ cases, and lobectomy or hemithyroidectomy in 114 (91.2\%) cases. The skin was incised for about $3 \mathrm{~cm}$ for hemithyroidectomy and 4-5 cm for total thyroidectomy. The Lap Protector Mini ${ }^{\circledR}$ (HAKKO Co. Ltd., Chikuma, Japan) was used to protect the wound margin, an intraoperative nerve monitoring (IONM) device (NIM Nerve Monitoring Systems; Medtronic, Minneapolis, MN) was used to avoid injuring the recurrent or the superior laryngeal nerves in a narrow field of vision. Lymph node dissection was performed in all cases: $82.4 \%$ underwent central compartment (D1) dissection, which was expanded to lateral compartments in $17.6 \%$ (D2 16\%, D3 1.6\%).

The reasons for the high number of lobectomies performed in Fukushima, which contrasts with the surgical reports from Chernobyl $(60,61)$, are the following. Patients are of a young age, and in Japan, radioisotope therapy after total thyroidectomy is not recommended for such patients. Furthermore, there is also a problem of psychological distress and the reduction of compliance resulting from the lasting hormone administration after total thyroidectomy in young patients. Thus, lobectomy was performed, considering these reasons as well as the consensus among thyroid experts in Japan.

\section{Pathological diagnosis}

The postoperative pathological diagnosis revealed 121 $(98.6 \%)$ cases of PTC, three cases of poorly differentiated carcinoma, and one case of thyroid cancer whose final diagnosis is pending. The PTCs included 110 cases of the classical type, four cases of the follicular variant, three cases of the diffuse sclerosing variant, and four cases of the cribriform-morular variant. The relatively high incidence of the latter subtype is associated with familial adenomatous polyposis. This could be seen as one advantage of the screening program, as detection of the previously undiagnosed underlying genetic condition would have enabled earlier treatment of the gastrointestinal component of this condition, illustrating the potential merit of screening.

Intrathyroidal spread was observed in $61.6 \%$, and calcifications, such as psammoma bodies, were observed in $78.4 \%$. The rates of lymph node metastasis and extrathyroidal tumor extension were also high, especially the rate of lymph node metastasis, which exceeded $70 \%$. These findings, as well as a high rate of intrathyroidal spread and of calcifications, however, are common for childhood PTC $(59,62)$. The details of histopathological analysis of cases from Fukushima are currently under examination.

\section{Complications}

Except for the patients who underwent total thyroidectomy, no cases of hypothyroidism were observed, except in a patient who received thyroid hormone before the operation because of Hashimoto's thyroiditis. Subclinical hypothyroidism with a slight thyrotropin elevation was observed in a few cases. Neither hypoparathyroidism nor postoperative bleeding occurred. Unilateral prolonged paralysis of the recurrent laryngeal nerve was documented in one $(0.8 \%)$ case.

\section{Effect of Screening}

Considering the benefits and the drawbacks of screening, diagnostic criteria of the primary examination of children and adolescents with a good prognosis should be such that unnecessary confirmatory examinations are avoided as much as possible, although health checkups should continue uninterrupted for a long period. The rate of category A2 findings (nodules $\leq 5 \mathrm{~mm}$ and/or cysts $\leq 20 \mathrm{~mm}$ ) was high $(47.8 \%)$. Most were cysts, which led to the arguments, both within Japan and overseas, that the rate of those had rapidly increased in Fukushima because of radiation. Later, at the request of the Ministry of the Environment of Japan, the Japan Association of Breast and Thyroid Sonology conducted surveys following the same procedure as in Fukushima in Aomori, Yamanashi, and Nagasaki Prefectures, resulting in the detection of a high rate of category A2 findings (56.5\%), which is thought to be high due to the high resolution of the ultrasonographs used $(63,64)$. Incidentally, the subjects examined in the three Prefectures were aged $\geq 3$ years, which was slightly older than those in Fukushima. In the Fukushima first full-scale survey (second screening), however, the age of the evaluated subjects increased for two to three years, and the rate of category A2 findings rose to $59 \%$, which was similar to the survey results in the three Prefectures. This is due to the fact that cysts are observed less frequently in infants and are more prevalent in school-age children (49).

\section{Understanding Thyroid Cancer in Fukushima}

According to the studies reported until now, it is difficult at this point to attribute thyroid cancers in Fukushima to the direct effects of radiation exposure. The reasons are as follows. Exposure doses in Fukushima are significantly lower than those in Chernobyl (65). There is no apparent regional difference in the rate of thyroid cancer cases among the residential areas at the time of the earthquake and, hence, exposure status of the patients $(50,66)$. The mean age of the subjects diagnosed with thyroid cancer was $10-15$ years at the time of accident, while there were no cases in younger children (aged 0-5 years for the first four years), who are more vulnerable to radiation exposure (67-69). Although it is expected that thyroid cancer will also be detected at certain frequencies in those who were infants at the time of accident after some years, its causes need to be specially investigated. The pathological findings are similar in children from nonexposed areas. Lastly, the frequency of $B R A F$ gene mutations among all genetic alterations in cancer tissue is high, nearly the same as in adult thyroid cancers, and the frequency of gene rearrangement is substantially lower than that in Chernobyl $(35,36)$. 
Importantly, increased detection rates and subsequent overtreatment linked to this are an issue $(70,71)$. The criteria of ultrasound examinations need to be set reasonably upon reaching a consensus among Japanese thyroid experts and considering all benefits and drawbacks $(49,50,58)$. It is becoming apparent that the frequency of discovering adult thyroid cancer has increased worldwide $(72,73)$, and increased detection by ultrasound imaging is attracting attention as one of the causes. In Korea, the rate of FNAC for small tumors was $94.4 \%$, and it was $100 \%$ if the tumor size was $>5 \mathrm{~mm}$ until 2009. As a result of considering increased detection, the rate decreased to $53.5 \%$ in 2014 for tumors $<5 \mathrm{~mm}$ and to $80.2 \%$ for those $>5 \mathrm{~mm}$ with the annual decrease in operations by $35 \%$ (74). The possibility of increased detection under very special circumstances after the accident in Fukushima cannot be ruled out. However, operative indications as well as FNAC indications were considered carefully. The FNAC rate in Fukushima is about $10 \%$ for nodules $5-10 \mathrm{~mm}$ in size if the examination criteria are strictly followed.

While new measures to solve these issues are necessary, the latest ATA management guidelines for children and adults with thyroid nodules also have benefits and disadvantages $(75,76)$. The use of individual treatment strategies according to risk assessment based on surgical findings of PTC has been proposed. Its foundation is the fact that PTC may comprise high-risk, low-risk, as well as very low-risk tumors (e.g., latent cancer or microcarcinoma in some cases). The latter reflects a "silent" cancer (or precancerous lesion), which does not progress to a clinically significant tumor during the patient's lifetime. These findings, however, are mostly based on surgical experience and retrospective analysis in adult patients and/or autopsy studies, and it is difficult to project those directly onto children, adolescents, and young adults. In this regard, further follow-up of the Fukushima cohort may provide unique insights into the incidence and natural history of small tumors in young individuals and, with time, shed light on the problem of whether the tumors detected and treated at a young age will change the incidence of larger tumors in the aging cohort (69).

In any case, the individual prognosis cannot be accurately determined at the time of FNAC at present. It is therefore urgent to search not only for intraoperative and postoperative prognostic factors but also for predictive prognostic factors at the FNAC/preoperative stage. To develop better guidelines on thyroid examination after a nuclear accident, the positive experience of natural observational follow-up of cases with a good prognosis should be considered. The Japanese experience with this approach in the management of adult thyroid microcarcinomas can be provided as an example of improving the quality of care (77). The experience accumulating for papillary thyroid microcarcinomas illustrates that there is an ongoing need to reduce and prevent inappropriate detection and subsequent overtreatment.

\section{Conclusion}

The lessons from Fukushima show the necessity of correct understanding of the issues on radiation and the thyroid. Epidemiological studies conducted thus far demonstrate that the dose-dependent risk of radiation-induced thyroid cancer can be assessed and used for projections in the population once exposure has taken place. These predictions are not applicable, however, at the individual level or in situations with a very low exposure dose. Radiation risk assessment, radiation safety, and protection are very different problems, which are not always easy to comprehend. The accident at the Fukushima Nuclear Power Plant caused a biased risk perception, which is now a pressing social problem similar to that observed after Chernobyl $(78,79)$. Consequently, the association between radiation and the thyroid has reminded people of the reiteration of Chernobyl and brought about a simplistic way of assuming that the high incidence of thyroid cancers has been caused by radiation exposure. This, in turn, has further augmented excessive anxiety, worries, and wrong interpretations of the results of elaborate large-scale ultrasound thyroid screening, having a psychological and mental impact on those exposed to radiation (80). It is thus necessary to deepen the understanding of radiation and the thyroid, both among healthcare professionals and the public, and to develop appropriate radiation risk communication by examining in detail the data of long-term epidemiological surveys and by studying the relation with the exposure dose and other factors, and to rely on the insights provided by cancer biology and genetics. The lessons from Fukushima emphasize the importance of education in radiation risk and proper understanding of thyroid cancer biology $(54,81,82)$. These observations also provide a valuable opportunity to reconsider the significance, benefits, and disadvantages of early diagnosis and treatment of thyroid cancer.

Finally, one more area of concern emanating from misunderstanding of radiological consequences and screening results is that it is critical to avoid irrational stigmatization of the children of Fukushima (82), bearing in mind that anyone may have disease or seeds of disease yet live a healthy life.

\section{Acknowledgments}

We are grateful to everybody who has been contributing to the difficult Fukushima Health Management Survey project after the Fukushima Nuclear Power Plant accident. We also heartily pray for the late Dr. Shigenobu Nagataki, professor emeritus of Nagasaki University, who was a world authority in radiation and the thyroid. Publication of this work was supported in part by KAKENHI Grant Number 16H02774 from the Japan Society for the Promotion of Science (JSPS).

\section{Author Disclosure Statement}

No competing financial interests exist.

\section{References}

1. Yamashita S, Thomas G (eds) 2017 Thyroid Cancer and Nuclear Accidents: Long-Term Aftereffects of Chernobyl and Fukushima. Academic Press, Elsevier, Inc., Cambridge, MA.

2. Ohtsuru A, Tanigawa K, Kumagai A, Niwa O, Takamura N, Midorikawa S, Nollet K, Yamashita S, Ohto H, Chhem RK, Clarke M 2015 Nuclear disasters and health: lessons learned, challenges, and proposals. Lancet 386:489-497.

3. Yasumura S, Hosoya M, Yamashita S, Kamiya K, Abe M, Akashi M, Kodama K, Ozasa K, Fukushima Health Management Survey G 2012 Study protocol for the Fukushima Health Management Survey. J Epidemiol 22:375-383.

4. Furukawa K, Preston D, Funamoto S, Yonehara S, Ito M, Tokuoka S, Sugiyama H, Soda M, Ozasa K, Mabuchi K 2013 Long-term trend of thyroid cancer risk among Japanese 
atomic-bomb survivors: 60 years after exposure. Int J Cancer 132:1222-1226.

5. Kazakov VS, Demidchik EP, Astakhova LN 1992 Thyroid cancer after Chernobyl. Nature 359:21.

6. Mizuno T, Iwamoto KS, Kyoizumi S, Nagamura H, Shinohara T, Koyama K, Seyama T, Hamatani K 2000 Preferential induction of RET/PTC1 rearrangement by X-ray irradiation. Oncogene 19:438-443.

7. Hamatani K, Eguchi H, Ito R, Mukai M, Takahashi K, Taga M, Imai K, Cologne J, Soda M, Arihiro K, Fujihara M, Abe K, Hayashi T, Nakashima M, Sekine I, Yasui W, Hayashi Y, Nakachi K 2008 RET/PTC rearrangements preferentially occurred in papillary thyroid cancer among atomic bomb survivors exposed to high radiation dose. Cancer Res 68: 7176-7182.

8. Caudill CM, Zhu Z, Ciampi R, Stringer JR, Nikiforov YE 2005 Dose-dependent generation of RET/PTC in human thyroid cells after in vitro exposure to gamma-radiation: a model of carcinogenic chromosomal rearrangement induced by ionizing radiation. J Clin Endocrinol Metab 90: 2364-2369.

9. Yamashita S, Takamura N, Ohtsuru A, Suzuki S 2016 Radiation exposure and thyroid cancer risk after the $\mathrm{Fu}-$ kushima buclear power plant accident in comparison with the Chernobyl accident. Radiat Prot Dosimetry 171:41-46.

10. Kitahara CM, Sosa JA 2016 The changing incidence of thyroid cancer. Nat Rev Endocrinol 12:646-653.

11. United Nations Scientific Committee on the Effects of Atomic Radiation 2014 Sources and effects of ionizing radiation. UNSCEAR 2013 Report to the General Assembly with scientific annexes. Volume I, Annex A: Levels and effects of radiation exposure due to the nuclear accident after the 2011 Great east-Japan earthquake and tsunami. Available at: www.unscear.org/docs/publications/2013/ UNSCEAR_2013_GA-Report.pdf (accessed May 17, 2017).

12. International Atomic Energy Agency 2015 The Fukushima Daiichi accident. Available at: www-pub.iaea.org/books/ IAEABooks/10962/The-Fukushima-Daiichi-Accident (accessed May 17, 2017).

13. Rothman K, Greenland S, Lash TL 2008 Modern Epidemiology. Third edition. Lippincott Williams \& Wilkins, Philadelphia, PA.

14. Veiga LH, Holmberg E, Anderson H, Pottern L, Sadetzki S, Adams MJ, Sakata R, Schneider AB, Inskip P, Bhatti P, Johansson R, Neta G, Shore R, de Vathaire F, Damber L, Kleinerman R, Hawkins MM, Tucker M, Lundell M, Lubin JH 2016 Thyroid cancer after childhood exposure to external radiation: an updated pooled analysis of 12 studies. Radiat Res 185:473-484.

15. Lubin JH, Adams MJ, Shore R, Holmberg E, Schneider AB, Hawkins MM, Robison LL, Inskip PD, Lundell M, Johansson R, Kleinerman RA, de Vathaire F, Damber L, Sadetzki S, Tucker M, Sakata R, Veiga LH 2017 Thyroid cancer following childhood low dose radiation exposure: a pooled analysis of nine cohorts. J Clin Endocrinol Metab 102:2575-2583.

16. Cardis E, Kesminiene A, Ivanov V, Malakhova I, Shibata Y, Khrouch V, Drozdovitch V, Maceika E, Zvonova I, Vlassov O, Bouville A, Goulko G, Hoshi M, Abrosimov A, Anoshko J, Astakhova L, Chekin S, Demidchik E, Galanti R, Ito M, Korobova E, Lushnikov E, Maksioutov M, Masyakin V, Nerovnia A, Parshin V, Parshkov E, Piliptsevich N, Pinchera A, Polyakov S, Shabeka N, Suonio E, Tenet V, Tsyb A, Yamashita S, Williams D 2005 Risk of thyroid cancer after exposure to $131 \mathrm{I}$ in childhood. J Natl Cancer Inst 97:724-732.

17. United Nations Scientific Committee on the Effects of Atomic Radiation 2011 Sources and effects of ionizing radiation. UNSCEAR 2008 Report to the General Assembly with scientific annexes. Volume II, Scientific Annex D: Health effects due to radiation from the Chernobyl accident. United Nations, New York, NY.

18. International Commission on Radiological Protection 2009 Application of the Commission's Recommendations for the Protection of People in Emergency Exposure Situations. ICRP Publication 109. Ann. ICRP 39 (1).

19. Kim E, Kurihara O, Kunishima N, Momose T, Ishikawa T, Akashi M 2016 Internal thyroid doses to Fukushima residents-estimation and issues remaining. J Radiat Res 57:i118-i126.

20. Drozd VM, Saenko VA, Brenner AV, Drozdovitch V, Pashkevich VI, Kudelsky AV, Demidchik YE, Branovan I, Shiglik N, Rogounovitch TI, Yamashita S, Biko J, Reiners C 2015 Major factors affecting incidence of childhood thyroid cancer in Belarus after the Chernobyl accident: do nitrates in drinking water play a role? PLoS One 10:e0137226.

21. Lim H, Devesa SS, Sosa JA, Check D, Kitahara CM 2017 Trends in thyroid cancer incidence and mortality in the United States, 1974-2013. JAMA 317:1338-1348.

22. Saenko VA, Thomas GA, Yamashita S 2017 Meeting report: the 5th International Expert Symposium in Fukushima on radiation and health. Environ Health 16:3.

23. Demidchik YE, Saenko VA, Yamashita S 2007 Childhood thyroid cancer in Belarus, Russia, and Ukraine after Chernobyl and at present. Arq Bras Endocrinol Metabol 51: 748-762.

24. Zablotska LB, Ron E, Rozhko AV, Hatch M, Polyanskaya ON, Brenner AV, Lubin J, Romanov GN, McConnell RJ, O'Kane P, Evseenko VV, Drozdovitch VV, Luckyanov N, Minenko VF, Bouville A, Masyakin VB 2011 Thyroid cancer risk in Belarus among children and adolescents exposed to radioiodine after the Chornobyl accident. Br J Cancer 104: 181-187.

25. Brenner AV, Tronko MD, Hatch M, Bogdanova TI, Oliynik VA, Lubin JH, Zablotska LB, Tereschenko VP, McConnell RJ, Zamotaeva GA, O'Kane P, Bouville AC, Chaykovskaya LV, Greenebaum E, Paster IP, Shpak VM, Ron E 2011 I-131 dose response for incident thyroid cancers in Ukraine related to the Chornobyl accident. Environ Health Perspect 119:933-939.

26. Yamashita S, Saenko VA 2017 What is the "screening effect" six years after the Fukushima nuclear power plant accident? Thyroid 27:595-596.

27. Ivanov VK KV, Chekin SYu, Maksioutov MA, Tumanov KA, Meniailo AN, Vlasov OK, Kochergina EV, Kashcheeva PV, Shchukina NV, Galkin VN, Kaprin AD, Saenko VA, Yamashita S 2016 Thyroid cancer: lessons of Chernobyl and projections for Fukushima. Radiat Risk 25:5-19 (in Russian). English abstract available at: www.radiationand-risk.com/en/year2016-en/issue2/969-1 (accessed July 19, 2017).

28. Fagin JA, Wells SA Jr 2016 Biologic and clinical perspectives on thyroid cancer. N Engl J Med 375:1054-1067.

29. Nikiforov YE, Nikiforova MN 2011 Molecular genetics and diagnosis of thyroid cancer. Nat Rev Endocrinol 7: $569-580$.

30. Nikiforova MN, Stringer JR, Blough R, Medvedovic M, Fagin JA, Nikiforov YE 2000 Proximity of chromosomal 
loci that participate in radiation-induced rearrangements in human cells. Science 290:138-141.

31. Hamatani K, Eguchi H, Koyama K, Mukai M, Nakachi K, Kusunoki Y 2014 A novel RET rearrangement (ACBD5/ RET) by pericentric inversion, inv(10)(p12.1;q11.2), in papillary thyroid cancer from an atomic bomb survivor exposed to high-dose radiation. Oncol Rep 32:1809-1814.

32. Klugbauer S, Lengfelder E, Demidchik EP, Rabes HM 1995 High prevalence of RET rearrangement in thyroid tumors of children from Belarus after the Chernobyl reactor accident. Oncogene 11:2459-2467.

33. Ricarte-Filho JC, Li S, Garcia-Rendueles ME, MonteroConde C, Voza F, Knauf JA, Heguy A, Viale A, Bogdanova T, Thomas GA, Mason CE, Fagin JA 2013 Identification of kinase fusion oncogenes in post-Chernobyl radiation-induced thyroid cancers. J Clin Invest 123:49354944.

34. Cancer Genome Atlas Research Network 2014 Integrated genomic characterization of papillary thyroid carcinoma. Cell 159:676-690.

35. Mitsutake N, Fukushima T, Matsuse M, Rogounovitch T, Saenko V, Uchino S, Ito M, Suzuki K, Suzuki S, Yamashita S $2015 B R A F(V 600 E)$ mutation is highly prevalent in thyroid carcinomas in the young population in Fukushima: a different oncogenic profile from Chernobyl. Sci Rep 5: 16976.

36. Iyama K, Matsuse M, Mitsutake N, Rogounovitch $T$, Saenko V, Suzuki K, Ashizawa M, Ookouchi C, Suzuki S, Mizunuma H, Fukushima T, Suzuki S, Yamashita S 2017 Identification of three novel fusion oncogenes, SQSTM1/ NTRK3, AFAP1L2/RET, and PPFIBP2/RET, in thyroid cancers of young patients in Fukushima. Thyroid 27:811818.

37. Dom G, Tarabichi M, Unger K, Thomas G, OczkoWojciechowska M, Bogdanova T, Jarzab B, Dumont JE, Detours V, Maenhaut C 2012 A gene expression signature distinguishes normal tissues of sporadic and radiationinduced papillary thyroid carcinomas. Br J Cancer 107: 994-1000.

38. Handkiewicz-Junak D, Swierniak M, Rusinek D, OczkoWojciechowska M, Dom G, Maenhaut C, Unger K, Detours V, Bogdanova T, Thomas G, Likhtarov I, Jaksik R, Kowalska M, Chmielik E, Jarzab M, Swierniak A, Jarzab B 2016 Gene signature of the post-Chernobyl papillary thyroid cancer. Eur J Nucl Med Mol Imaging 43:1267-1277.

39. Kaiser JC, Meckbach R, Eidemuller M, Selmansberger M, Unger K, Shpak V, Blettner M, Zitzelsberger H, Jacob P 2016 Integration of a radiation biomarker into modeling of thyroid carcinogenesis and post-Chernobyl risk assessment. Carcinogenesis 37:1152-1160.

40. Cipollini M, Figlioli G, Maccari G, Garritano S, De Santi C, Melaiu O, Barone E, Bambi F, Ermini S, Pellegrini G, Cristaudo A, Foddis R, Bonotti A, Romei C, Vivaldi A, Agate L, Molinari E, Barale R, Forsti A, Hemminki K, Elisei R, Gemignani F, Landi S 2016 Polymorphisms within base and nucleotide excision repair pathways and risk of differentiated thyroid carcinoma. DNA Repair (Amst) 41:27-31.

41. Gudmundsson J, Sulem P, Gudbjartsson DF, Jonasson JG, Sigurdsson A, Bergthorsson JT, He H, Blondal T, Geller F, Jakobsdottir M, Magnusdottir DN, Matthiasdottir S, Stacey SN, Skarphedinsson OB, Helgadottir H, Li W, Nagy R, Aguillo E, Faure E, Prats E, Saez B, Martinez M, Eyjolfsson GI, Bjornsdottir US, Holm H, Kristjansson K,
Frigge ML, Kristvinsson H, Gulcher JR, Jonsson T, Rafnar $\mathrm{T}$, Hjartarsson $\mathrm{H}$, Mayordomo JI, de la Chapelle A, Hrafnkelsson J, Thorsteinsdottir U, Kong A, Stefansson K 2009 Common variants on 9q22.33 and 14q13.3 predispose to thyroid cancer in European populations. Nat Genet 41: 460-464.

42. Gudmundsson J, Sulem P, Gudbjartsson DF, Jonasson JG, Masson G, He H, Jonasdottir A, Sigurdsson A, Stacey SN, Johannsdottir H, Helgadottir HT, Li W, Nagy R, Ringel MD, Kloos RT, de Visser MC, Plantinga TS, den Heijer M, Aguillo E, Panadero A, Prats E, Garcia-Castano A, De Juan A, Rivera F, Walters GB, Bjarnason H, Tryggvadottir L, Eyjolfsson GI, Bjornsdottir US, Holm H, Olafsson I, Kristjansson K, Kristvinsson H, Magnusson OT, Thorleifsson G, Gulcher JR, Kong A, Kiemeney LA, Jonsson T, Hjartarson H, Mayordomo JI, Netea-Maier RT, de la Chapelle A, Hrafnkelsson J, Thorsteinsdottir U, Rafnar T, Stefansson K 2012 Discovery of common variants associated with low TSH levels and thyroid cancer risk. Nat Genet 44:319-322.

43. Gudmundsson J, Thorleifsson G, Sigurdsson JK, Stefansdottir L, Jonasson JG, Gudjonsson SA, Gudbjartsson DF, Masson G, Johannsdottir H, Halldorsson GH, Stacey SN, Helgason H, Sulem P, Senter L, He H, Liyanarachchi S, Ringel MD, Aguillo E, Panadero A, Prats E, GarciaCastano A, De Juan A, Rivera F, Xu L, Kiemeney LA, Eyjolfsson GI, Sigurdardottir O, Olafsson I, Kristvinsson H, Netea-Maier RT, Jonsson T, Mayordomo JI, Plantinga TS, Hjartarson H, Hrafnkelsson J, Sturgis EM, Thorsteinsdottir U, Rafnar T, de la Chapelle A, Stefansson K 2017 A genome-wide association study yields five novel thyroid cancer risk loci. Nat Commun 8: 14517.

44. Takahashi M, Saenko VA, Rogounovitch TI, Kawaguchi T, Drozd VM, Takigawa-Imamura H, Akulevich NM, Ratanajaraya C, Mitsutake N, Takamura N, Danilova LI, Lushchik ML, Demidchik YE, Heath S, Yamada R, Lathrop M, Matsuda F, Yamashita S 2010 The FOXE1 locus is a major genetic determinant for radiation-related thyroid carcinoma in Chernobyl. Hum Mol Genet 19:2516-2523.

45. Matsuse M, Takahashi M, Mitsutake N, Nishihara E, Hirokawa M, Kawaguchi T, Rogounovitch T, Saenko V, Bychkov A, Suzuki K, Matsuo K, Tajima K, Miyauchi A, Yamada R, Matsuda F, Yamashita S 2011 The FOXE1 and NKX2-1 loci are associated with susceptibility to papillary thyroid carcinoma in the Japanese population. J Med Genet 48:645-648.

46. Nikitski AV, Rogounovitch TI, Bychkov A, Takahashi M, Yoshiura KI, Mitsutake N, Kawaguchi T, Matsuse M, Drozd VM, Demidchik Y, Nishihara E, Hirokawa M, Miyauchi A, Rubanovich AV, Matsuda F, Yamashita S, Saenko VA 2017 Genotype analyses in the Japanese and Belarusian populations reveal independent effects of rs965513 and rs1867277 but do not support the role of FOXE1 polyalanine tract length in conferring risk for papillary thyroid carcinoma. Thyroid 27:224-235.

47. Rogounovitch TI, Bychkov A, Takahashi M, Mitsutake N, Nakashima M, Nikitski AV, Hayashi T, Hirokawa M, Ishigaki $\mathrm{K}$, Shigematsu $\mathrm{K}$, Bogdanova $\mathrm{T}$, Matsuse $\mathrm{M}$, Nishihara E, Minami S, Yamanouchi K, Ito M, Kawaguchi T, Kondo H, Takamura N, Ito Y, Miyauchi A, Matsuda F, Yamashita S, Saenko VA 2015 The common genetic variant rs944289 on chromosome 14q13.3 associates with risk of both malignant and benign thyroid tumors in the Japanese population. Thyroid 25:333-340. 
48. Nikitski A, Saenko V, Shimamura M, Nakashima M, Matsuse M, Suzuki K, Rogounovitch T, Bogdanova T, Shibusawa N, Yamada M, Nagayama Y, Yamashita S, Mitsutake N 2016 Targeted Foxe1 overexpression in mouse thyroid causes the development of multinodular goiter but does not promote carcinogenesis. Endocrinology 157:2182-2195.

49. Suzuki S, Yamashita S, Fukushima T, Nakano K, Midorikawa S, Ohtsuru A, Yasumura S, Hosoya M, Kamiya K, Shimura H, Suzuki S, Nakamura I, Abe M 2016 The protocol and preliminary baseline survey results of the thyroid ultrasound examination in Fukushima [Rapid Communication]. Endocr J 63:315-321.

50. Suzuki S, Suzuki S, Fukushima T, Midorikawa S, Shimura H, Matsuzuka T, Ishikawa T, Takahashi H, Ohtsuru A, Sakai A, Hosoya M, Yasumura S, Nollet KE, Ohira T, Ohto H, Abe M, Kamiya K, Yamashita S 2016 Comprehensive survey results of childhood thyroid ultrasound examinations in Fukushima in the first four years after the Fukushima Daiichi Nuclear Power Plant accident. Thyroid 26:843-851.

51. Ishikawa T, Yasumura S, Ozasa K, Kobashi G, Yasuda H, Miyazaki M, Akahane K, Yonai S, Ohtsuru A, Sakai A, Sakata R, Kamiya K, Abe M 2015 The Fukushima Health Management Survey: estimation of external doses to residents in Fukushima Prefecture. Sci Rep 5:12712.

52. Suzuki S 2017 The features of childhood and adolescent thyroid cancer after Fukushima nuclear power plant accident. In: Yamashita S, Thomas G (eds) Thyroid Cancer and Nuclear Accidents. Long-term aftereffects of Chernobyl and Fukushima. Academic Press, Elsevier, Inc., Cambridge, MA, pp 155-163.

53. Radiation Medical Science Center FMU. The 27th Prefectural Oversight Committee Meeting for Fukushima Health Management Survey. Available at: http://fmu-global.jp/survey/ proceedings-of-the-27th-prefectural-oversight-committeemeeting-for-fukushima-health-management-survey/ (accessed July 18, 2017).

54. Midorikawa S, Tanigawa K, Suzuki S, Ohtsuru A 2017 Psychosocial issues related to thyroid examination after a radiation disaster. Asia Pac J Public Health 29:63S-73S.

55. Suzuki S, Midorikawa S, Fukushima T, Shimura H, Ohira T, Ohtsuru A, Abe M, Shibata Y, Yamashita S, Suzuki S; Thyroid Examination Unit of the Radiation Medical Science Center for the Fukushima Health Management Survey 2015 Systematic determination of thyroid volume by ultrasound examination from infancy to adolescence in Japan: the Fukushima Health Management Survey. Endocr J 62:261-268.

56. Fukushima T, Suzuki S, Ohira T, Shimura H, Midorikawa S, Ohtsuru A, Sakai A, Abe M, Yamashita S, Suzuki S; Thyroid Examination Unit of the Radiation Medical Center for the Fukushima Health Management Survey 2015 Prevalence of ectopic intrathyroidal thymus in Japan: the Fukushima Health Management Survey. Thyroid 25:534-537.

57. Suzuki S, Midorikawa S, Matsuzuka T, Fukushima T, Ito Y, Shimura H, Takahashi H, Ohira T, Ohtsuru A, Abe M, Suzuki S, Yamashita S 2017 Prevalence and characterization of thyroid hemiagenesis in Japan: the Fukushima Health Management Survey. Thyroid 27:1011-1016.

58. Suzuki S 2016 Childhood and adolescent thyroid cancer in Fukushima after the Fukushima Daiichi Nuclear Power Plant accident: 5 years on. Clin Oncol (R Coll Radiol) 28: 263-271.

59. Shirahige $Y$, Ito M, Ashizawa K, Motomura T, Yokoyama N, Namba H, Fukata S, Yokozawa T, Ishikawa N, Mimura
T, Yamashita S, Sekine I, Kuma K, Ito K, Nagataki S 1998 Childhood thyroid cancer: comparison of Japan and Belarus. Endocr J 45:203-209.

60. Demidchik YE, Demidchik EP, Reiners C, Biko J, Mine M, Saenko VA, Yamashita S 2006 Comprehensive clinical assessment of 740 cases of surgically treated thyroid cancer in children of Belarus. Ann Surg 243:525-532.

61. Rumyantsev PO, Saenko VA, Ilyin AA, Stepanenko VF, Rumyantseva UV, Abrosimov AY, Lushnikov EF, Rogounovitch TI, Shibata Y, Mitsutake N, Tsyb AF, Yamashita S 2011 Radiation exposure does not significantly contribute to the risk of recurrence of Chernobyl thyroid cancer. J Clin Endocrinol Metab 96:385-393.

62. Grigsby PW, Gal-or A, Michalski JM, Doherty GM 2002 Childhood and adolescent thyroid carcinoma. Cancer 95: 724-729.

63. Hayashida N, Imaizumi M, Shimura H, Okubo N, Asari Y, Nigawara T, Midorikawa S, Kotani K, Nakaji S, Otsuru A, Akamizu T, Kitaoka M, Suzuki S, Taniguchi N, Yamashita $\mathrm{S}$, Takamura N, Investigation Committee for the Proportion of Thyroid Ultrasound F 2013 Thyroid ultrasound findings in children from three Japanese Prefectures: Aomori, Yamanashi and Nagasaki. PLoS One 8: 83220.

64. Hayashida N, Imaizumi M, Shimura H, Furuya F, Okubo N, Asari Y, Nigawara T, Midorikawa S, Kotani K, Nakaji S, Ohtsuru A, Akamizu T, Kitaoka M, Suzuki S, Taniguchi N, Yamashita S, Takamura N 2015 Thyroid ultrasound findings in a follow-up survey of children from three Japanese Prefectures: Aomori, Yamanashi, and Nagasaki. Sci Rep 5: 9046.

65. Nagataki S, Takamura N 2016 Radioactive doses—predicted and actual-and likely health effects. Clin Oncol (R Coll Radiol) 28:245-254.

66. Ohira T, Takahashi H, Yasumura S, Ohtsuru A, Midorikawa S, Suzuki S, Fukushima T, Shimura H, Ishikawa T, Sakai A, Yamashita S, Tanigawa K, Ohto H, Abe M, Suzuki S, Fukushima Health Management Survey Group 2016 Comparison of childhood thyroid cancer prevalence among 3 areas based on external radiation dose after the Fukushima Daiichi Nuclear Power Plant accident: the Fukushima Health Management Survey. Medicine (Baltimore) 95: e4472.

67. Tronko MD, Saenko VA, Shpak VM, Bogdanova TI, Suzuki S, Yamashita S 2014 Age distribution of childhood thyroid cancer patients in Ukraine after Chernobyl and in Fukushima after the TEPCO-Fukushima Daiichi NPP accident. Thyroid 24:1547-1548.

68. Takamura N, Orita M, Saenko V, Yamashita S, Nagataki S, Demidchik Y 2016 Radiation and risk of thyroid cancer: Fukushima and Chernobyl. Lancet Diabetes Endocrinol 4:647.

69. Williams D 2015 Thyroid Growth and Cancer. Eur Thyroid J 4:164-173.

70. Ahn HS, Kim HJ, Welch HG 2014 Korea's thyroid-cancer "epidemic" — screening and overdiagnosis. N Engl J Med 371:1765-1767.

71. Shibuya K, Gilmour S, Oshima A 2014 Time to reconsider thyroid cancer screening in Fukushima. Lancet 383: 1883-1884.

72. Bae JM 2015 Overdiagnosis: epidemiologic concepts and estimation. Epidemiol Health 37:e2015004.

73. Vaccarella S, Franceschi S, Bray F, Wild CP, Plummer M, Dal Maso L 2016 Worldwide thyroid-cancer epidemic? The increasing impact of overdiagnosis. N Engl J Med 375: 614-617. 
74. Ahn HS, Welch HG 2015 South Korea's thyroid-cancer "epidemic" — turning the tide. N Engl J Med 373:2389-2390.

75. Francis GL, Waguespack SG, Bauer AJ, Angelos P, Benvenga S, Cerutti JM, Dinauer CA, Hamilton J, Hay ID, Luster M, Parisi MT, Rachmiel M, Thompson GB, Yamashita S; American Thyroid Association Guidelines Task Force 2015 Management guidelines for children with thyroid nodules and differentiated thyroid cancer. Thyroid 25:716-759.

76. Haugen BR, Alexander EK, Bible KC, Doherty GM, Mandel SJ, Nikiforov YE, Pacini F, Randolph GW, Sawka AM, Schlumberger M, Schuff KG, Sherman SI, Sosa JA, Steward DL, Tuttle RM, Wartofsky L 20162015 American Thyroid Association management guidelines for adult patients with thyroid nodules and differentiated thyroid cancer: the American Thyroid Association Guidelines Task Force on Thyroid Nodules and Differentiated Thyroid Cancer. Thyroid 26:1-133.

77. Ito Y, Miyauchi A, Oda H 2017 Low-risk papillary microcarcinoma of the thyroid: a review of active surveillance trials. Eur J Surg Oncol 2017 Mar 15 [Epub ahead of print]; DOI: 10.1016/j.ejso.2017.03.004.

78. Yamashita S, Carr Z, Repacholi M 2007 Long-term health implications of the Chernobyl accident and relevant projects of the World Health Organization. Health Phys 93:538-541.

79. Yamashita S 2014 Tenth Warren K. Sinclair keynote address - the Fukushima nuclear power plant accident and comprehensive health risk management. Health Phys 106: 166-180.

80. Normile D 2016 Epidemic of fear. Science 351:1022-1023.

81. Yasui K, Kimura Y, Kamiya K, Miyatani R, Tsuyama N, Sakai A, Yoshida K, Yamashita S, Chhem R, Abdel-Wahab M, Ohtsuru A 2017 Academic responses to Fukushima disaster. Asia Pac J Public Health 29:99S-109S.

82. Ochi S, Kato S, Tsubokura M, Leppold C, Kami M, Shibuya K 2016 Voice from Fukushima: responsibility of epidemiologists to avoid irrational stigmatization of children in Fukushima. Thyroid 26:1332-1333.

83. Radiation Medical Science Center, Fukushima Medican University. Thyroid Ultrasound Examination (Preliminary Baseline Screening). Supplemental Report of the FY 2016 Survey. Available at: http://fmu-global.jp/download/thyroidultrasound-examination-first-full-scale-thyroid-screeningprogram-5/?wpdmdl=2690 (accessed July 18, 2017).

84. Radiation Medical Science Center, Fukushima Medical University. Report of Second-Round Thyroid Ultrasound Examinations (First Full-Scale Thyroid Screening Program). Available at: http://fmu-global.jp/download/thyroidultrasound-examination-first-full-scale-thyroid-screeningprogram-5/?wpdmdl=2692 (accessed July 18, 2017).

85. Radiation Medical Science Center, Fukushima Medical University. Report of Third-Round Thyroid Ultrasound Examinations (Second Full-Scale Thyroid Screening Program). Available at: http://fmu-global.jp/download/thyroidultrasound-examination-second-full-scale-thyroid-screeningprogram-7/?wpdmdl=2693 (accessed July 18, 2017).

86. Radiation Medical Science Center, Fukushima Medical University. Fukushima Health Management Survey. Available at: http://fmu-global.jp/fukushima-health-managementsurvey/ (accessed July 18, 2017).

Address correspondence to: Shunichi Yamashita, MD, PhD Department of Radiation Medical Sciences Atomic Bomb Disease Institute Nagasaki University 1-12-4 Sakamoto Nagasaki 852-8523 Japan

E-mail: shun@nagasaki-u.ac.jp 